\title{
Taxonomic Note: Use of Patent Strains as Type Strains in the Valid Description of New Microbial Taxa
}

\author{
D. P. LABEDA, ${ }^{*}$ C. P. KURTZMAN, AND J. L. SWEZEY \\ Microbial Properties Research, National Center for Agricultural Utilization Research, Agricultural \\ Research Service, U.S. Department of Agriculture, Peoria, Illinois 61604
}

During the recent meeting of the Judicial Commission of the International Committee on Systematic Bacteriology (2), it was pointed out that Rule 27 of the International Code of Nomenclature of Bacteria (5) states that "[i]t is recommended that the type of a species or subspecies be deposited in a recognized culture collection" and that Recommendation 30a (5) states that "the type strain. . . should be deposited in at least one of the permanently established culture collections, from which it would be made readily available." The problem raised during Judicial Commission discussions concerns type strains that are the subjects of pending patents and thus may not be freely available. The Judicial Commission considered it mandatory that such strains be made available to the scientific community and that names should not be validated until the organisms are available for study. The latest Instructions to Authors for the International Journal of Systematic Bacteriology in the January 1995 issue recommends that patent strains other than type strains should carry the superscript " $P$ " if the patent has been issued and the superscript "PP" if the patent is pending. These revised instructions also strongly suggest that a new species description cannot be published while a patent is pending on an intended type strain because of the potential restrictions on its availability. The Judicial Commission suggested that Recommendation 30 a should be made a rule, and the new Instructions to Authors state that the editor will enforce this rule.

The Agricultural Research Service (ARS) Culture Collection at the Northern Regional Research Laboratory (NRRL) in Peoria, Ill., became the world's first official patent culture collection when the chlorotetracycline-producing strain Streptomyces aureofaciens NRRL 2209 was deposited in 1949 at the request of the United States Patent Office (3) and is one of 26 International Depositary Authorities, or IDAs, for patent strain deposits recognized worldwide under the Budapest Treaty (6). In view of our long-term experience with patent culture deposits, we were asked to address the problems stemming from the discussion mentioned above and appropriate procedures associated with the use of patent strains as type strains for new taxa.

Although previously valid publication of taxonomic descriptions of new taxa associated with patent applications was often delayed until the patent was issued in the United States or until the patent application was published after 18 months in Europe, there is now a trend toward valid publication of new taxon names before the patent is issued or the European patent application is published. The problems which arise from the use of patent strains as type material involve the restrictions regarding strain distribution because of patent regulations and policies, which make the strains potentially unavail-

* Corresponding author. Mailing address: National Center for Agricultural Utilization Research, 1815 North University Street, Peoria, IL 61604. able to the scientific community until the patent is issued or the application is published in European patents.

Patent strains are deposited in specific recognized culture collections primarily as a requirement of the patent application process. Distribution of the strains is restricted until the patent is issued or the patent application is published in Europe, and if the application is abandoned, as sometimes occurs, the strain will never be made available to the public unless access is authorized by the original depositor.

An example of the latter scenario occurred with Amycolatopsis azurea NRRL 11412, which was deposited in the ARS Patent Culture Collection in 1978. This strain was described as the type strain of Pseudonocardia azurea and was cited as the type strain by Ōmura et al. (4). Strain NRRL 11412 was transferred to the genus Amycolatopsis as an A. azurea strain, and it was cited again, along with the equivalent designation DSM 43854 , as the type strain (1). This strain was freely available from the Deutsche Sammlung von Mikroorganismen und Zellkulturen, since it had been obtained directly from S. Ömura with no distribution restrictions, but because the United States patent application was abandoned, it was never released for distribution by the ARS Patent Culture Collection. Thus, strain NRRL 11412 was not even available to other taxonomic researchers in the ARS Culture Collection. S. Ömura was recently contacted regarding the patent status of this strain, and he released it by letter on 26 March 1993, making it available from the ARS Culture Collection.

Under Budapest Treaty Rule 9.2 (6), an International Depositary Authority is not permitted to acknowledge the existence of a strain in its collection until the patent has been issued, a request for a sample has been certified by a patent office, or the strain is released by the depositor. Within our collection, even after the patent is issued, policy demands that a strain can be distributed only upon receipt of an original (not facsimiled) signed letter specifically requesting the strain by both taxonomic name and depositor strain number or collection accession number.

Under patent law, a strain is released by a patent culture collection upon issuance of a patent (Budapest Treaty Rule $11.3[\mathrm{~b}]$ ), to parties legally entitled to the strain after certification of a request for a sample by a patent office (Budapest Treaty Rule 11.3[a]), or upon written authorization for release of the strain by the original depositor or a designated agent (Budapest Treaty Rule 11.2[ii]). The latter method of strain release is the primary means for a prospective author to make a patent strain available to the scientific community prior to publication of the European patent application or issuance of the patent elsewhere when the strain is to be described in a taxonomic paper as the type reference material of a new species. The letter of release generally states that the strain is made available to the public for taxonomic purposes, but not for the practice of the invention, which is a violation of patent law in any case. In most instances the patent application also includes a substance of matter claim for the active material 
produced by the strain or a process claim for the method in which the strain is used or both, which precludes anyone from legally practicing the invention, and thus release of the strain for taxonomic purposes should not jeopardize the patent.

The use of unreleased patent strains as type material in descriptions of new taxa is clearly not acceptable, as reflected by the new editorial policy of the International Journal of Systematic Bacteriology, since comparative studies of this material by workers in other laboratories would not be possible for at least 18 months in the case of a European patent application or for an indeterminable period of time until the patent in question has finally been issued in most other countries. Thus, during the intervening time before release, the taxon could not be considered validly published, because the scientific community would not have access to the type material. Furthermore, anyone publishing a description based on a conspecific strain which is freely available to the public would have priority for valid publication of the new taxon. As a matter of course, we routinely check the availability of strains cited in manuscripts presenting new valid taxonomic descriptions before we begin our review. If the strains are restricted patent deposits, the manuscripts are returned without review, unless the authors have provided a statement that the strains cited will be promptly released by letter for taxonomic purposes upon publication of the paper.

\section{REFERENCES}

1. Henssen, A., H. W. Kothe, and R. M. Kroppenstedt. 1987. Transfer of Pseudonocardia azurea and "Pseudonocardia fastidiosa" to the genus Amycolatopsis, with emended species description. Int. J. Syst. Bacteriol. 37:292-295.

2. Judicial Commission of the International Committee on Systematic Bacteriology. 1995. Minutes of the meetings, 2 and 6 July 1994, Prague, Czech Republic. Int. J. Syst. Bacteriol. 45:195-196.

3. Kurtzman, C. P. 1986. The ARS Culture Collection: present status and new directions. Enzyme Microb. Technol. 8:328-333.

4. Ōmura, S., H. Tanaka, Y. Tanaka, P. Spiri-Nakagawa, R. Ōmura, Y. Takahashi, H. Matsuyama, and Y. Iwai. 1979. Studies on bacterial cell wall inhibitors. VII. Azureomycins A and B, new antibiotics produced by Pseudonocardia azurea nov. $\mathrm{sp}$. Taxonomy of the producing organism, isolation, characterization and biological properties. J. Antibiot. 32:985-994.

5. Sneath, P. H. A. (ed.). 1992. International code of nomenclature of bacteria. 1990 Revision. American Society for Microbiology, Washington, D.C.

6 . The Budapest Treaty on the International Recognition of the Deposit of Microorganisms for the Purpose of Patent Procedure. 1977. Official Gazette of the U.S. Patent Trademark Office 961:21-36. 